\title{
Effects of Initial Nitrate Concentrations and Photocatalyst Dosages on Ammonium Ion in Synthetic Wastewater Treated by Photocatalytic Reduction
}

\author{
Orawan Rojviroon $\mathbb{D D}^{1}$ Sanya Sirivithayapakorn ${ }^{1}{ }^{1}{ }^{1}$ Thammasak Rojviroon ${ }^{(D)}{ }^{2}$ \\ and Chalermraj Wantawin $\left.{ }^{1}\right)^{1}$ \\ ${ }^{1}$ Department of Environmental Engineering, Faculty of Engineering, Kasetsart University, Bangkok 10900, Thailand \\ ${ }^{2}$ Division of Environmental Engineering, Faculty of Engineering, Rajamangala University of Technology Thanyaburi, \\ Pathum Thani 12110, Thailand
}

Correspondence should be addressed to Sanya Sirivithayapakorn; fengsys@ku.ac.th

Received 6 August 2020; Revised 16 October 2020; Accepted 24 October 2020; Published 16 November 2020

Academic Editor: Jiangwei LIU

Copyright () 2020 Orawan Rojviroon et al. This is an open access article distributed under the Creative Commons Attribution License, which permits unrestricted use, distribution, and reproduction in any medium, provided the original work is properly cited.

\begin{abstract}
Ammonium $\left(\mathrm{NH}_{4}^{+}\right)$is an undesirable by-product of photocatalytic nitrate $\left(\mathrm{NO}_{3}^{-}\right)$reduction since it is harmful to aquatic life once it converts into ammonia $\left(\mathrm{NH}_{3}\right)$. This research investigated the removal efficiency of $\mathrm{NO}_{3}^{-}$and for the first time quantified the relationships of initial nitrate concentrations $\left(\left[\mathrm{NO}_{3}^{-}\right]_{0}\right)$ and photocatalyst dosages on the remaining ammonium $\left(\mathrm{NH}_{4}^{+}\right)$in synthetic wastewater using photocatalytic reduction process with either nanoparticle titanium dioxide $\left(\mathrm{TiO}_{2}\right)$ or $1.0 \% \mathrm{Ag}_{-} \mathrm{TiO}{ }_{2}$ under Ultraviolet A (UVA). The experiments were systematically carried out under various combinations of $\left[\mathrm{NO}_{3}^{-}\right]_{0}(10,25,50$, 80 , and $100 \mathrm{mg}-\mathrm{N} / \mathrm{L})$ and photocatalyst dosages $(0.1,0.5,1.0$, and $2.0 \mathrm{~g})$. The $\mathrm{NO}_{3}^{-}$removal efficiency of both photocatalysts was 98.96-99.98\%, and the catalytic selectivity products were nitrogen gas $\left(\mathrm{N}_{2}\right)$, nitrite $\left(\mathrm{NO}_{2}^{-}\right)$, and $\mathrm{NH}_{4}^{+}$. Of the two photocatalysts under comparable experimental conditions, $1.0 \% \mathrm{Ag}-\mathrm{TiO}_{2}$ provided better $\mathrm{NO}_{3}^{-}$removal efficiency. For both photocatalysts, the remaining $\mathrm{NH}_{4}^{+}$was predominantly determined by $\left[\mathrm{NO}_{3}^{-}\right]_{0}$; higher $\left[\mathrm{NO}_{3}^{-}\right]_{0}$ led to higher $\mathrm{NH}_{4}^{+}$. Multiple linear regression analysis confirmed the dominant role of $\left[\mathrm{NO}_{3}^{-}\right]_{0}$ in the remaining $\mathrm{NH}_{4}^{+}$. The photocatalyst dosage could play an essential role in limiting $\mathrm{NH}_{4}^{+}$in the treated wastewater, with large variation in $\left[\mathrm{NO}_{3}^{-}\right]_{0}$ from different sources.
\end{abstract}

\section{Introduction}

Photocatalytic reduction is an effective technology for removal of nitrate $\left(\mathrm{NO}_{3}^{-}\right)$in wastewater. The major disadvantage of this process is the ammonium $\left(\mathrm{NH}_{4}^{+}\right)$, an undesirable by-product, remaining at the end. Many researchers studied $\mathrm{NO}_{3}^{-}$removal efficiency and the $\mathrm{NO}_{3}^{-}$conversion selectivity [1-3]. There are also studies on the influencing factors on the remaining $\mathrm{NH}_{4}^{+}$, which investigated the relationships between remaining $\mathrm{NH}_{4}^{+}$and those influencing factors in the process.

Previous studies demonstrated that high efficiency nitrate removal by photocatalytic reduction with low remaining $\left[\mathrm{NH}_{4}^{+}\right]$could be achieved by silver- (Ag-) doped $\mathrm{TiO}_{2}$ nano- particles under high-performance light sources (i.e., highpressure Hg lamps and xenon lamps) [4-6]. However, those light sources have disadvantages that include high energy consumption, potential human health hazard, and generating high heat $[7,8]$. For those reasons, the UVA light bulb is chosen for this process because it overcomes those disadvantages and is powerful enough for this process [9-11].

The influencing factors of the photocatalytic selectivity of $\mathrm{NO}_{3}^{-}$conversion include initial nitrate concentration $\left(\left[\mathrm{NO}_{3}^{-}\right.\right.$ ]$_{0}$ ), light source intensity, type of photocatalyst, type of dopant, and quantity of photocatalyst dosage $[4,12,13]$. Evidence shows that manipulating the photocatalytic selectivity of photocatalytic reduction helps limit environmentally harmful compounds, particularly $\mathrm{NH}_{4}^{+}[14,15] . \mathrm{NH}_{4}^{+}$is 
harmful to aquatic life once in the natural waterways where it converts into ammonia $\left(\mathrm{NH}_{3}\right)$. According to the United States Environmental Protection Agency (US EPA), the upper safety limit of total ammonia nitrogen $\left(\mathrm{NH}_{3}-\mathrm{N}\right)$ is $17 \mathrm{mg}-\mathrm{N} / \mathrm{L}$ (1-hour average) and $1.9 \mathrm{mg}-\mathrm{N} / \mathrm{L}$ (30-day rolling average) at $\mathrm{pH} 7.0$ and $20^{\circ} \mathrm{C}$ for acute and chronic criteria, respectively [16]. The reported total ammonia concentrations in treated wastewater from photocatalytic reduction vary between 0.07 and $57.8 \mathrm{mg}-\mathrm{N} / \mathrm{L}$ [4, 17-22].

Doping of silver $\left(\mathrm{Ag}^{+}\right)$on photocatalysts, especially $\mathrm{TiO}_{2}$, to improve the photocatalytic performance was a common practice. Previous studies applied $0.1 \%-7.0 \% \mathrm{Ag}^{+}$loading on $\mathrm{TiO}_{2}$ photocatalysts and found that $1 \% \mathrm{Ag}^{+}$was the most optimum dose to enhance the photocatalytic $\mathrm{NO}_{3}^{-}$reduction activity [23-25].

This research investigated the effects of initial nitrate concentrations $\left(\left[\mathrm{NO}_{3}^{-}\right]_{0}\right)$ and photocatalyst dosages on $\mathrm{NO}_{3}^{-}$ removal efficiency in synthetic wastewater using photocatalytic reduction. The experiments were carried out under various $\left[\mathrm{NO}_{3}^{-}\right]_{0}(10,25,50,80$, and $100 \mathrm{mg}-\mathrm{N} / \mathrm{L})$ and photocatalyst dosages $(0.1,0.5,1.0$, and $2.0 \mathrm{~g})$ under UVA irradiation as light source for photocatalytic nitrate reduction. The experimental photocatalysts were $\mathrm{TiO}_{2}$ and $1.0 \% \mathrm{Ag}-\mathrm{TiO}_{2}$ nanoparticle as photocatalysts [21]. The catalytic selectivity of $\mathrm{NO}_{3}^{-}$conversion was also determined, and the actual concentrations of $\mathrm{NH}_{4}^{+}$under different experimental $\mathrm{NO}_{3}^{-}$removal conditions were compared. Multiple linear regression was performed to characterize the relationship between the remaining $\mathrm{NH}_{4}^{+}$and $\left[\mathrm{NO}_{3}^{-}\right]_{0}$ and photocatalyst dosages. Essentially, the novelty of this research lies in the use of $\mathrm{TiO}_{2}$ nanopowder as photocatalyst, as opposed to commercial-grade $\mathrm{TiO}_{2}$. By comparison, $\mathrm{TiO}_{2}$ nanopowder possesses larger surface area for adsorption and reaction. Another research novelty is the systematical use of various $\left[\mathrm{NO}_{3}^{-}\right]_{0}$ and photocatalyst dosages, unlike previous researches which experimented with specific $\left[\mathrm{NO}_{3}^{-}\right]_{0}$ and photocatalyst dosages.

\section{Materials and Methodology}

2.1. $\mathrm{Ag}-\mathrm{TiO}_{2}$ Photocatalyst Preparation and Characteristics. In this research, $1.0 \% \mathrm{Ag}-\mathrm{TiO}_{2}$ photocatalyst was prepared by composite colloid deposition under alkaline condition, following Doudrick et al. [4,9] with minor modifications. In the experiment, $12 \mathrm{~g}$ of $\mathrm{TiO}_{2}$ nanopowder was dispersed in $500 \mathrm{~mL}$ deionized water and purged with nitrogen gas $\left(\mathrm{N}_{2}\right)$ for $30 \mathrm{~min}$ to remove $\mathrm{O}_{2}$. After degassing, $8 \mathrm{~mL}$ of methanol was added and stirred prior to adding $\mathrm{NaOH}$ to adjust $\mathrm{pH}$ of the mixture to $12-13$. Afterward, $1.0 \% \mathrm{AgNO}_{3}(w / v$; Fluka) was added and stirred in the dark for $30 \mathrm{~min}$ before irradiation with UVA $\left(800 \mu \mathrm{W} / \mathrm{cm}^{2}\right)$ for $1 \mathrm{~h}$ at room temperature.

The mixture was then centrifuged at $200 \mathrm{rpm}$ for $2 \mathrm{~min}$ to settle the powder, and the supernatant was discarded. Deionized water was added to wash the powder. It was then stirred and centrifuged. The process was repeated until the mixture $\mathrm{pH}$ was 7. The washed powder was oven dried at $103^{\circ} \mathrm{C}$ for $24 \mathrm{~h}$ and calcined at $450^{\circ} \mathrm{C}$ for $1 \mathrm{~h}$ for $\mathrm{Ag}-\mathrm{TiO}_{2}$ photocatalyst in the form of dried light purple powder.
The experimental $\mathrm{TiO}_{2}$ nanopowder was of $15 \mathrm{~nm}$ in particle size and $99.5 \%$ anatase crystalline phase (US Research Nanomaterials, Inc., USA). The composition and specific surface area of dose photocatalysts were characterized by transmission electron microscopy (TEM, JEM-1400 TEM instrument) and X-ray fluorescence spectrometer (XRF; Bruker model S8 Tiger), Brunauer, Emmett and Teller (BET) analyzer (BELSORP-max Bel Japan Inc.).

2.2. Photocatalytic Reduction for $\mathrm{NO}_{3}^{-}$Removal. The photocatalytic reduction to remove nitrate $\left(\mathrm{NO}_{3}^{-}\right)$was carried out using $\mathrm{TiO}_{2}$ and $\mathrm{Ag}-\mathrm{TiO}_{2}$ photocatalysts in $125 \mathrm{~mL}$ cylindrical borosilicate glass photoreactor. Figure 1 illustrates the schematic of experimental photocatalytic reduction for $\mathrm{NO}_{3}^{-}$ removal. Synthetic $\mathrm{NO}_{3}^{-}$wastewater of variable initial nitrate concentrations was prepared by dissolving potassium nitrate $\left(\mathrm{KNO}_{3}>99 \%\right.$, Fluka) in deionized water. The initial nitrate concentration $\left(\left[\mathrm{NO}_{3}^{-}\right]_{0}\right)$ varied between $10,25,50,80$, and $100 \mathrm{mg}-\mathrm{N} / \mathrm{L}$.

The photoreactor was filled with $100 \mathrm{~mL}$ synthetic wastewater of varying $\left[\mathrm{NO}_{3}^{-}\right]_{0}$ and $58 \mathrm{mM}$ of formic acid (FA) as hole scavenger, with the mixture $\mathrm{pH}$ ranging from 2.28 to 2.42. $\mathrm{TiO}_{2}$ and $\mathrm{Ag}-\mathrm{TiO}_{2}$ photocatalysts of varying dosages were independently added into the photoreactor. The photocatalyst dosage was varied from $0.1,0.5,1.0$, and $2.0 \mathrm{~g}$. The photoreactor condition was anaerobic by purging with $\mathrm{N}_{2}$ for $30 \mathrm{~min}$ to remove dissolved oxygen (DO) in the synthetic wastewater.

Prior to UVA irradiation, samples were drawn for initial measurement of $\mathrm{pH}, \mathrm{DO},\left[\mathrm{NH}_{4}^{+}\right],\left[\mathrm{NO}_{2}^{-}\right]$, and $\left[\mathrm{NO}_{3}^{-}\right]$. The samples were subsequently irradiated with two UVA light bulbs ( $300 \mathrm{~W}$, Osram) for $6 \mathrm{~h}$. The UVA light bulbs were located on either side of the photoreactor vessel at a distance of $20 \mathrm{~cm}$. The UVA intensity in the photoreactor vessel was $800 \mu \mathrm{W} / \mathrm{cm}^{2}$ on average. The concentrations of $\mathrm{NO}_{3}^{-}$and by-products $\left(\left[\mathrm{NO}_{2}^{-}\right]\right.$and $\left.\left[\mathrm{NH}_{4}^{+}\right]\right)$relative to reaction time were periodically measured throughout the experiment, while $\mathrm{pH}$ and $\mathrm{DO}$ were measured at the beginning and at termination (at $360 \mathrm{~min}$ ). The concentrations of $\mathrm{NO}_{3}^{-}, \mathrm{NO}_{2}^{-}$, and $\mathrm{NH}_{4}^{+}$in the synthesis wastewater were determined using ion chromatography instrument with chemical suppression (Metrohm 882 Compact IC Plus). Nitrogen gas $\left(\mathrm{N}_{2}\right)$ was calculated by the mass balance of nitrogen of the photocatalytic reduction process.

To verify the experiment, photocatalytic reduction was also carried out under three control conditions: (1) in the absence of photocatalyst but with UVA irradiation; (2) with $\mathrm{Ag}-\mathrm{TiO}_{2}$ photocatalyst of varying dosages but without UVA irradiation; and (3) with $\mathrm{TiO}_{2}$ photocatalysts of varying dosages but without UVA irradiation. The measured $\left[\mathrm{NO}_{3}^{-}\right]$, $\left[\mathrm{NO}_{2}^{-}\right]$, and $\left[\mathrm{NH}_{4}^{+}\right]$of photocatalytic reduction using Ag$\mathrm{TiO}_{2}$ and $\mathrm{TiO}_{2}$ photocatalysts irradiated with UVA were subsequently compared against the controls.

2.3. Selectivity of Photocatalytic Reduction for $\mathrm{NO}_{3}^{-}$Removal. The $\mathrm{NO}_{3}^{-}$removal efficiency of photocatalytic reduction $(\eta)$ and the catalytic selectivity $(S)$ of $\mathrm{NO}_{3}^{-}$into $\mathrm{NH}_{4}^{+}, \mathrm{NO}_{2}^{-}$, and $\mathrm{N}_{2}$ (denoted by $S_{\mathrm{NH}_{4}^{+}}, S_{\mathrm{NO}_{2}^{-}}$, and $S_{\mathrm{N}_{2}}$ ) $[21,26]$ are 


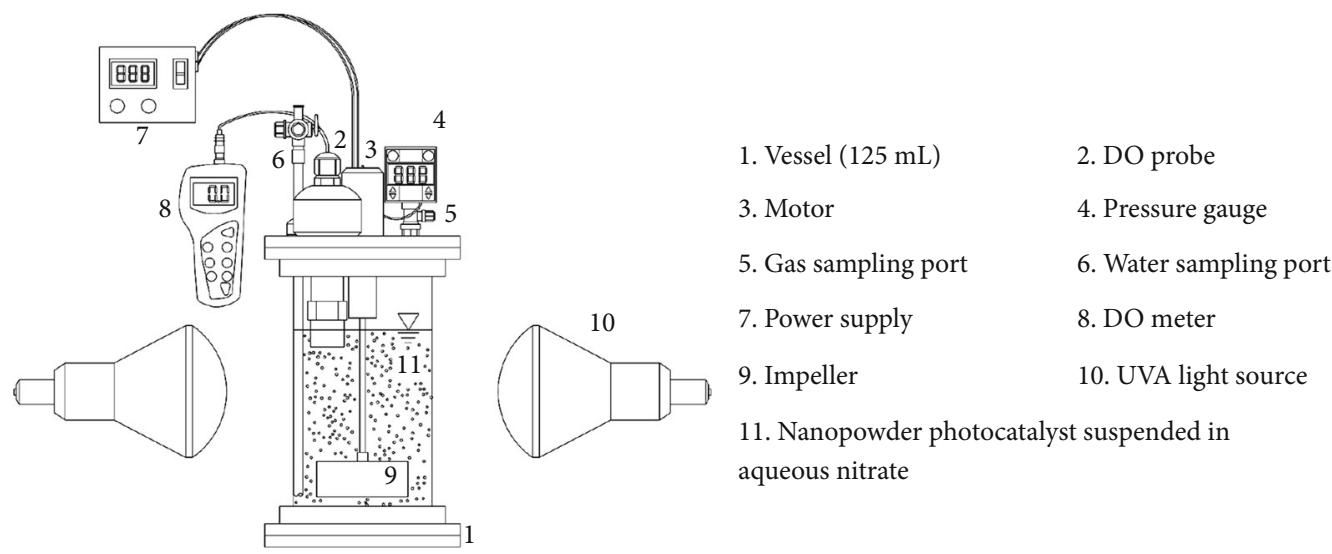

Figure 1: Schematic of photoreactor for nitrate removal.

mathematically expressed in the following equations.

$$
\begin{gathered}
\eta=\frac{\left[\mathrm{NO}_{3}^{-}\right]_{0}-\left[\mathrm{NO}_{3}^{-}\right]_{t}}{\left[\mathrm{NO}_{3}^{-}\right]_{0}} \times 100 \\
\% S_{\mathrm{NO}_{2}^{-}}=\frac{\left[\mathrm{NO}_{2}^{-}\right]_{t}}{\left[\mathrm{NO}_{3}^{-}\right]_{0}-\left[\mathrm{NO}_{3}^{-}\right]_{t}} \times 100 \\
\% S_{\mathrm{NH}_{4}^{+}}=\frac{\left[\mathrm{NH}_{4}^{+}\right]_{t}}{\left[\mathrm{NO}_{3}^{-}\right]_{0}-\left[\mathrm{NO}_{3}^{-}\right]_{t}} \times 100 \\
\% S_{\mathrm{N}_{2}}=\frac{\left[\mathrm{NO}_{3}^{-}\right]_{0}-\left[\mathrm{NO}_{3}^{-}\right]_{t}-\left[\mathrm{NO}_{2}^{-}\right]_{t}-\left[\mathrm{NH}_{4}^{+}\right]_{t}}{\left[\mathrm{NO}_{3}^{-}\right]_{0}-\left[\mathrm{NO}_{3}^{-}\right]_{t}} \times 100
\end{gathered}
$$

where $[X]_{0}$ is the initial concentration of $X$ and $[X]_{t}$ is the concentration of $X$ at time $t$.

\section{Results and Discussion}

3.1. Ag-TiO ${ }_{2}$ Nanopowder Photocatalyst Characteristics. The results of transmission electron microscopy were used to examine the particle size and morphology of Ag nanoparticles on $\mathrm{TiO}_{2}$ as well as the lattice information of both photocatalysts investigated by XRF. In comparison, the TEM image of nano- $\mathrm{TiO}_{2}$ and nano-Ag- $\mathrm{TiO}_{2}$ photocatalysts (Figure 2) showed a similar particle size and morphology with average particle size (in diameter) of approximately $15 \mathrm{~nm}$ (as the result of the average $\mathrm{TiO}_{2}$ particle size before Ag doping). The results of the TEM analysis were not clearly distinguishable in terms of particle size and morphology although it was reported that Ag doping would slightly decrease the particle size of the larger $\mathrm{TiO}_{2}$ powders [27].

The XRF patterns of $\mathrm{TiO}_{2}$ and $1.0 \% \mathrm{Ag}-\mathrm{TiO}_{2}$ nanopowder photocatalysts showed strong peaks of $\mathrm{Ti}$, as shown in Figure 3 . The XRF pattern of $1.0 \% \mathrm{Ag}-\mathrm{TiO}_{2}$ photocatalyst indicated that $\mathrm{Ag}^{+}$dopant was effectively doped onto $\mathrm{TiO}_{2}$ which is the same with the theoretical adding. The Ag dopant in $\mathrm{Ag}-\mathrm{TiO}_{2}$ phase was $0.99 \%$ for theoretical doping of $1.0 \%$ (Table 1). It was confirmed that Ag was effectively deposited on the surface of $\mathrm{TiO}_{2}$ nanopowder. Specifically, $\mathrm{Ag}^{+}$ions were adsorbed onto the crystal structure of $\mathrm{TiO}_{2}$ and subsequently formed $\mathrm{Ag}-\mathrm{TiO}_{2}[28,29]$.
The BET specific surface areas of $\mathrm{TiO}_{2}$ and $1.0 \% \mathrm{Ag}-\mathrm{TiO}_{2}$ nanopowder photocatalysts were $1.164 \times 10^{2}$ and $1.124 \times$ $10^{2} \mathrm{~m}^{2} / \mathrm{g}$, and the corresponding pore volumes were 4.727 $\times 10^{-7}$ and $3.951 \times 10^{-7} \mathrm{~m}^{3} / \mathrm{g}$. It was found that the specific surface area and pore volume of $\mathrm{Ag}-\mathrm{TiO}_{2}$ were decreased after doping. The findings were consistent with previous studies which doped $\mathrm{TiO}_{2}$ nanopowder photocatalysts with varying dopants $[4,30,31]$.

The slightly decreased BET surface areas and pore volume were due to the interference of Ag dopant on the formation of anatase crystallization [32, 33], and a marked influence on the microstructures was exhibited by calcination temperature [34]. However, the advantage of metal doping on semiconductor particles, $\mathrm{Ag}-\mathrm{TiO}_{2}$, was the prevention of recombination between electron and hole by trapping the electron on the metal surface resulting in increasing the lifetime of electron in conduction band, thus enhancing the efficiency of photocatalytic nitrate reduction [34].

3.2. $\mathrm{NO}_{3}^{-}$Removal Using Photocatalytic Reduction. The $\mathrm{NO}_{3}^{-}$ removal efficiency $(\eta)$ of photocatalytic reduction using $\mathrm{TiO}_{2}$ and $1.0 \% \mathrm{Ag}-\mathrm{TiO}_{2}$ photocatalysts under variable initial $\mathrm{NO}_{3}^{-}$concentrations $\left(\left[\mathrm{NO}_{3}^{-}\right]_{0} ; 10,25,50,80\right.$, and $100 \mathrm{mg}$ $\mathrm{N} / \mathrm{L})$ and $\mathrm{TiO}_{2}$ and $1.0 \% \mathrm{Ag}-\mathrm{TiO}_{2}$ dosages $(0.1,0.5,1.0$, and $2.0 \mathrm{~g}$ ) was determined by equation (1).

Table 2 tabulates the $\mathrm{NO}_{3}^{-}$removal efficiency, nitrate concentration at termination $\left(\left[\mathrm{NO}_{3}^{-}\right]_{\mathrm{t}}\right)$, ammonium ion selectivity $\left(\% \mathrm{~S}_{\mathrm{NH}_{4}^{+}}\right)$, and actual ammonium ion concentration $\left(\left[\mathrm{NH}_{4}^{+}\right.\right.$ ]$_{\mathrm{a}}$ ) of photocatalytic reduction under various $\left[\mathrm{NO}_{3}^{-}\right]_{0}$ using $\mathrm{TiO}_{2}$ and $1.0 \% \mathrm{Ag}-\mathrm{TiO}_{2}$ photocatalysts. The $\mathrm{NO}_{3}^{-}$removal efficiency of $\mathrm{TiO}_{2}$ and $1.0 \% \mathrm{Ag}-\mathrm{TiO}_{2}$ photocatalysts was 98.96-99.98\%. The $\mathrm{NO}_{3}^{-}$removal efficiency increased with the increase in photocatalyst dosage as the surface area for adsorption and reaction increased.

The ammonium ion selectivity $\left(\mathrm{S}_{\mathrm{NH}_{4}^{+}}\right)$and actual ammonium ion concentration $\left(\left[\mathrm{NH}_{4}^{+}\right]_{\mathrm{a}}\right)$ increased with the increase in photocatalyst dosage for both $\mathrm{TiO}_{2}$ and $1.0 \%$ Ag- $\mathrm{TiO}_{2}$ photocatalysts. In addition, the initial nitrate concentration and $\left[\mathrm{NH}_{4}^{+}\right]_{\mathrm{a}}$ were positively correlated. In other words, low $\left[\mathrm{NO}_{3}^{-}\right]_{0}$ resulted in low $\left[\mathrm{NH}_{4}^{+}\right]_{\mathrm{a}}$ and vice versa. Moreover, 


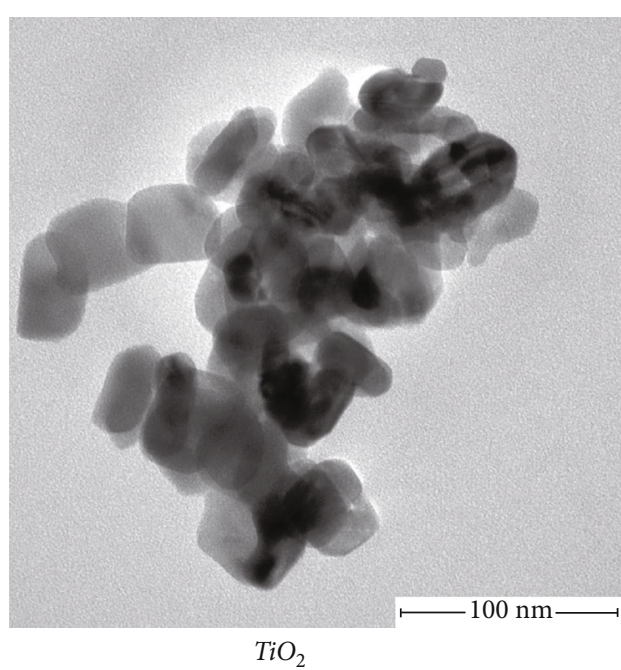

(a) $\mathrm{TiO}_{2}$

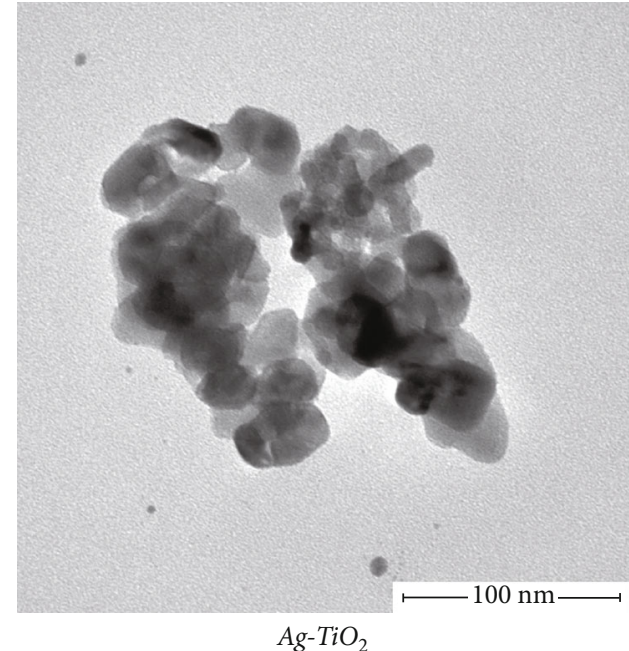

(b) $\mathrm{Ag}-\mathrm{TiO}_{2}$

FIgure 2: TEM image of (a) $\mathrm{TiO}_{2}$ photocatalyst and (b) $1.0 \% \mathrm{Ag}-\mathrm{TiO}_{2}$ photocatalyst.

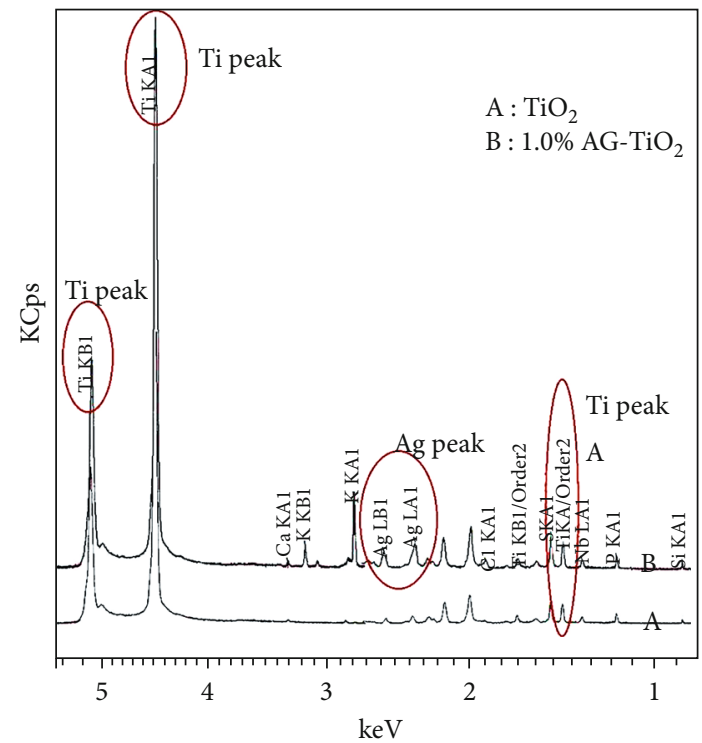

FIgure 3: The XRF patterns of $\mathrm{TiO}_{2}$ and $1.0 \% \mathrm{Ag}-\mathrm{TiO}_{2}$ nanopowder photocatalysts.

$\left[\mathrm{NH}_{4}^{+}\right]_{\mathrm{a}}$ of $1.0 \% \mathrm{Ag}-\mathrm{TiO}_{2}$ photocatalyst was higher than that of $\mathrm{TiO}_{2}$ photocatalyst under all experimental conditions.

The $\mathrm{NO}_{3}^{-}$reduction in photocatalytic process was a stepwise mechanism. When the photoinduced electrons $\left(\mathrm{e}^{-}\right)$in valence band were excited onto conduction band, holes $\left(\mathrm{h}^{+}\right)$appeared at valence band. This process was called electron-hole pairs photogeneration [32] (equation (5)). The photogenerated holes consumed $\mathrm{HCOO}^{-}$, and $\mathrm{CO}_{2}^{-}$was generated [35] (equation (6)). The $\mathrm{CO}_{2}^{--}$is a strong reducing agent to reduce $\mathrm{NO}_{3}^{-}$to either $\mathrm{NH}_{4}^{+}$or $\mathrm{N}_{2}$ (equations (7)-(12)), in which nitrite $\left(\mathrm{NO}_{2}^{-}\right.$ ) was an intermediate product. The results of $\mathrm{NO}_{2}^{-}, \mathrm{NH}_{4}^{+}$, and $\mathrm{N}_{2}$ in percent named the selectivity of $\mathrm{NO}_{3}^{-}$reduction.

$$
\mathrm{TiO}_{2}+\mathrm{hv} \rightarrow \mathrm{e}^{-}+\mathrm{h}^{+}
$$

$$
\begin{gathered}
\mathrm{HCOO}^{-}+\mathrm{h}^{+} \rightarrow \mathrm{H}^{+}+\mathrm{CO}_{2}^{-} \\
\mathrm{NO}_{3}^{-}+2 \mathrm{H}^{+}+2 \mathrm{e}^{-} \rightarrow \mathrm{NO}_{2}^{-}+\mathrm{H}_{2} \mathrm{O} \\
2 \mathrm{NO}_{3}^{-}+12 \mathrm{H}^{+}+10 \mathrm{CO}_{2}^{--} \rightarrow \mathrm{N}_{2}+6 \mathrm{H}_{2} \mathrm{O}+10 \mathrm{CO}_{2} \\
\mathrm{NO}_{3}^{-}+10 \mathrm{H}^{+}+8 \mathrm{CO}_{2}^{--} \rightarrow \mathrm{NH}_{4}^{+}+3 \mathrm{H}_{2} \mathrm{O}+8 \mathrm{CO}_{2} \\
\mathrm{NO}_{2}^{-}+8 \mathrm{H}^{+}+6 \mathrm{CO}_{2}^{--} \rightarrow \mathrm{NH}_{4}^{+}+2 \mathrm{H}_{2} \mathrm{O}+6 \mathrm{CO}_{2} \\
2 \mathrm{NO}_{3}^{-}+12 \mathrm{H}^{+}+10 \mathrm{e}^{-} \rightarrow \mathrm{N}_{2}+6 \mathrm{CO}_{2} \\
\mathrm{NO}_{3}^{-}+10 \mathrm{H}_{2} \mathrm{O}+8 \mathrm{e}^{-} \rightarrow \mathrm{NH}_{4}^{+}+3 \mathrm{H}_{2} \mathrm{O}
\end{gathered}
$$

In the nitrate reduction experiments, $58 \mathrm{mmol}$ of formic acid (FA) was used as a hole scavenger to improve the photocatalytic reduction reaction, while the $\mathrm{pH}$ of the solution increased from 2.28-2.42 to 2.41-5.5 due to the consumption of formic acid in the reaction and the generation of $\left[\mathrm{NH}_{4}^{+}\right]$. In addition, the highly efficient conversion of $\mathrm{NO}_{2}^{-}$to $\mathrm{N}_{2}$ was also related to the initial acidity of the solution [36]. This was probably due to the specific absorption properties of $\mathrm{NO}_{3}^{-}$and $\mathrm{NO}_{2}^{-}$in varying $\mathrm{pH}$ solutions. Considering that the point of zero charge of the $\mathrm{TiO}_{2}$ was 6.25 [37], in acidic solution, $\mathrm{TiO}_{2}$ surface accumulated a net positive charge due to the increasing fraction of $\mathrm{TiOH}_{2}^{+}$sites on the surface and $\mathrm{NO}_{2}^{-}$could be quickly adsorbed.

Figure 4 compares the nitrate concentrations of photocatalytic reduction under various $\left[\mathrm{NO}_{3}^{-}\right]_{0}$ and photocatalytic dosages $\left(\mathrm{TiO}_{2}\right.$ and $\left.1.0 \% \mathrm{Ag}-\mathrm{TiO}_{2}\right)$ from the start to end. In Figure 4 , the $\mathrm{NO}_{3}^{-}$removal was positively correlated with photocatalyst dosage due to the surface area effect, independent of photocatalyst type. Although at termination there were not much differences in final $\mathrm{NO}_{3}^{-}$removal efficiencies, the $\mathrm{NO}_{3}^{-}$removal rates of $1.0 \% \mathrm{Ag}-\mathrm{TiO}_{2}$ photocatalyst were faster than those of $\mathrm{TiO}_{2}$ photocatalyst for the comparable conditions. The faster removal rate of photocatalytic reduction activity was attributable to $\mathrm{Ag}^{+}$doping $[33,38]$. The loading of $\mathrm{TiO}_{2}$ with $\mathrm{Ag}^{+}$reduced the difference between 
TABLE 1: Composition of $\mathrm{TiO}_{2}$ and $1.0 \% \mathrm{Ag}-\mathrm{TiO}_{2}$ photocatalysts.

\begin{tabular}{|c|c|c|c|c|c|c|c|c|}
\hline \multirow{2}{*}{ Photocatalyst } & \multicolumn{6}{|c|}{ Composition (\%) } & \multirow{2}{*}{ BET surface area $\left(\mathrm{m}^{2} / \mathrm{g}\right)$} & \multirow{2}{*}{ Pore volume $\left(\mathrm{m}^{3} / \mathrm{g}\right)$} \\
\hline & $\mathrm{TiO}_{2}$ & $\mathrm{Ag}$ & $\mathrm{SiO}_{2}$ & $\mathrm{P}_{2} \mathrm{O}_{5}$ & $\mathrm{Nb}_{2} \mathrm{O}_{5}$ & Other & & \\
\hline $\mathrm{TiO}_{2}$ & 96.8 & - & 0.44 & 0.15 & 0.11 & 2.50 & $1.164 \times 10^{2}$ & $4.727 \times 10^{-7}$ \\
\hline $1.0 \% \mathrm{Ag}-\mathrm{TiO}_{2}$ & 96.1 & 0.99 & 0.40 & 0.17 & 0.11 & 2.23 & $1.124 \times 10^{2}$ & $3.951 \times 10^{-7}$ \\
\hline
\end{tabular}

TABLE 2: $\mathrm{NO}_{3}^{-}$removal efficiency, $\left[\mathrm{NO}_{3}^{-}\right]_{t}, \% S_{\mathrm{NH}_{4}^{+}}$, and $\left[\mathrm{NH}_{4}^{+}\right]_{\mathrm{a}}$ of photocatalytic reduction using $\mathrm{TiO}_{2}$ and $1.0 \% \mathrm{Ag}-\mathrm{TiO}{ }_{2}$ photocatalysts at termination.

\begin{tabular}{lcccccc}
\hline Photocatalyst & {$\left[\mathrm{NO}_{3}^{-}\right]_{0}(\mathrm{mg}-\mathrm{N} / \mathrm{L})$} & Dosage $(\mathrm{g})$ & $\mathrm{NO}_{3}^{-}$removal $(\%)$ & $\% S_{\mathrm{NH}_{4}^{+}}$ & {$[\mathrm{NH}+]_{\mathrm{a}}(\mathrm{mg}-\mathrm{N} / \mathrm{L})$} & $\mathrm{pH}$ \\
\hline & 10 & $0.1-2.0$ & $98.96-99.48$ & $25.81-34.00$ & $2.55-3.38$ & $2.41-2.84$ \\
& 25 & $0.1-2.0$ & $99.35-99.92$ & $20.53-36.5$ & $5.10-9.12$ \\
$\mathrm{TiO}_{2}$ & 50 & $0.1-2.0$ & $99.84-99.92$ & $9.53-26.40$ & $4.76-13.18$ \\
& 80 & $0.1-2.0$ & $99.85-99.98$ & $16.35-25.55$ & $13.06-20.43$ & $2.54-3.11$ \\
& 100 & $0.1-2.0$ & $99.90-99.95$ & $17.13-22.56$ & $17.12-22.55$ & $2.93-3.3$ \\
\hline & 10 & $0.1-2.0$ & $99.60-99.62$ & $19.71-64.09$ & $1.96-6.38$ \\
$1.0 \% \mathrm{Ag}^{-\mathrm{TiO}_{2}}$ & 25 & $0.1-2.0$ & $99.30-99.84$ & $17.59-44.81$ & $4.39-11.19$ \\
& 50 & $0.1-2.0$ & $99.78-99.90$ & $14.97-45.98$ & $7.47-22.97$ & $2.50-2.51$ \\
& 80 & $0.1-2.0$ & $99.85-99.94$ & $19.20-38.15$ & $15.33-30.50$ & $3.72-3.03$ \\
& 100 & $0.1-2.0$ & $99.82-99.96$ & $16.12-38.10$ & $16.09-38.10$ & $3.06-5.02$ \\
\hline
\end{tabular}

Note: $\% \mathrm{NH}_{4}^{+}$is $\mathrm{NH}_{4}^{+}$selectivity $(\%),\left[\mathrm{NH}_{4}^{+}\right]_{\mathrm{a}}$ is actual $\left[\mathrm{NH}_{4}^{+}\right]$, and $\mathrm{pH}_{t}$ is $\mathrm{pH}$ at the end.

energy levels of the valence and conduction bands, resulting in the extension of light absorption wavelength into the visible light region. $\mathrm{Ag}^{+}$also acted as a trap site for excited electrons, giving rise to electron-hole separation. In addition, $\mathrm{Ag}^{+}$doping enhanced charge transport, prolonged the lifetime of electron-hole pairs, and reduced the charge recombination [39-42]. As a result, $\mathrm{Ag}^{+}$could be adopted for photocatalytic reduction process to improve $\mathrm{NO}_{3}^{-}$removal.

Figure 5 illustrates the catalytic selectivity (\%) of photocatalytic reduction using $\mathrm{TiO}_{2}$ and $1.0 \% \mathrm{Ag}-\mathrm{TiO}_{2}$ photocatalysts in which $\mathrm{NO}_{3}^{-}$was transformed into $\mathrm{NO}_{2}^{-}, \mathrm{NH}_{4}^{+}$, and $\mathrm{N}_{2}$. The results showed that overall $\mathrm{N}_{2}$ accounted for the largest proportions of $\mathrm{NO}_{3}^{-}$by-products, followed by $\mathrm{NH}_{4}^{+}$and $\mathrm{NO}_{2}^{-}$.

In Figure 5, the photocatalyst types $\left(\mathrm{TiO}_{2}\right.$ and $1.0 \% \mathrm{Ag}$ $\mathrm{TiO}_{2}$ ) and dosage played a role in the selectivity of the photocatalytic reduction scheme. This showed that the Ag dopant enhanced the photocatalytic reduction activity, and both the activity and $\left[\mathrm{NH}_{4}^{+}\right]$increased with $1.0 \% \mathrm{Ag}-\mathrm{TiO}_{2}$ dosage increase. However, $1.0 \% \mathrm{Ag}-\mathrm{TiO}_{2}$ photocatalyst dosage beyond $0.1 \mathrm{~g}$ (i.e., $0.5,1.0$, and $2.0 \mathrm{~g}$ ) contributed to $\left[\mathrm{NH}_{4}^{+}\right]$ in the treated wastewater exceeding that of $\mathrm{TiO}_{2}$ photocatalyst (Table 2). $\mathrm{NH}_{4}^{+}$is harmful to aquatic life once in the natural waterways where it converts into $\mathrm{NH}_{3}$.

The initial nitrate concentrations also played a role in $\left[\mathrm{NH}_{4}^{+}\right]$in the treated wastewater, independent of photocatalyst type $\left(\mathrm{TiO}_{2}\right.$ and $\left.1.0 \% \mathrm{Ag}-\mathrm{TiO}_{2}\right)$. Specifically, higher $\left[\mathrm{NO}_{3}^{-}\right]_{0}$ resulted in higher $\left[\mathrm{NH}_{4}^{+}\right]$. Given $0.1 \mathrm{~g}$ of either $\mathrm{TiO}_{2}$ or $1.0 \% \mathrm{Ag}-\mathrm{TiO}_{2}$ photocatalyst, $\left[\mathrm{NH}_{4}^{+}\right]$was $1.96-16.09 \mathrm{mg}$ $\mathrm{N} / \mathrm{L}$, independent of $\left[\mathrm{NO}_{3}^{-}\right]_{0}$. Assuming complete $\mathrm{NH}_{4}^{+}$-to$\mathrm{NH}_{3}$ conversion, these were equivalent to $1.96-16.09 \mathrm{mg}-$ $\mathrm{N} / \mathrm{L}$ total ammonia nitrogen $\left(\mathrm{NH}_{3}-\mathrm{N}\right)$, which is below
$17 \mathrm{mg}-\mathrm{N} / \mathrm{L} \mathrm{NH}_{3}-\mathrm{N}$ of the US EPA [16]. Meanwhile, the nitrate concentrations of the three control conditions (i.e., the controls) remained unchanged at the end of the experiment.

In Figure 5, the catalytic selectivity of $\mathrm{NO}_{3}^{-}$into $\mathrm{NO}_{2}^{-}$ could also be observed. The remaining nitrite concentrations $\left(\left[\mathrm{NO}_{2}^{-}\right]\right)$were negligible as $\mathrm{NO}_{2}^{-}$was converted into $\mathrm{NH}_{4}^{+}$and $\mathrm{N}_{2}$ during the photocatalytic reduction process [43].

To comparatively investigate the effect of initial nitrate concentration and photocatalyst dosage on the concentration of ammonium ion, the relationships between $\left[\mathrm{NH}_{4}^{+}\right]$and $\left[\mathrm{NO}_{3}^{-}\right]_{0}$ and photocatalyst dosage $\left(\mathrm{TiO}_{2}\right.$ and $\left.1.0 \% \mathrm{Ag}-\mathrm{TiO}_{2}\right)$ were established by using statistical multiple linear regression. $\left[\mathrm{NH}_{4}^{+}\right],\left[\mathrm{NO}_{3}^{-}\right]_{0}$, and photocatalyst dosage are denoted by $Y, X_{1}$, and $X_{2}$, respectively. The multiple linear regression was expressed in equation (13), and Table 3 tabulates the regression results.

$$
Y=b+\beta_{1} X_{1}+\beta_{2} X_{2}+\cdots+\varepsilon,
$$

where $b$ is the linear regression constant, $\beta$ is the linear regression coefficient, and $\varepsilon$ is the error constant.

In Table $3, \beta$ of the initial nitrate concentration $\left(\left[\mathrm{NO}_{3}^{-}\right]_{0}\right)$ was, respectively, 0.925 and 0.838 for $\mathrm{TiO}_{2}$ and $1.0 \% \mathrm{Ag}-\mathrm{TiO}_{2}$ photocatalysts $(p<0.001)$, indicating that $\left[\mathrm{NO}_{3}^{-}\right]_{0}$ played the dominant role in $\mathrm{NO}_{3}^{-}$removal efficiency and the remaining $\mathrm{NH}_{4}^{+}$. Meanwhile, $\beta$ of photocatalyst dosage was 0.407 and 0.288 for $1.0 \% \mathrm{Ag}-\mathrm{TiO}_{2}$ and $\mathrm{TiO}_{2}$ photocatalysts, suggesting that the photocatalyst dosage had considerably less effect on the remaining $\mathrm{NH}_{4}^{+}$.

In reality, $\left[\mathrm{NO}_{3}^{-}\right]_{0}$ varies from area to area. Given diverse $\left[\mathrm{NO}_{3}^{-}\right]_{0}$, it is operationally practical to vary the 


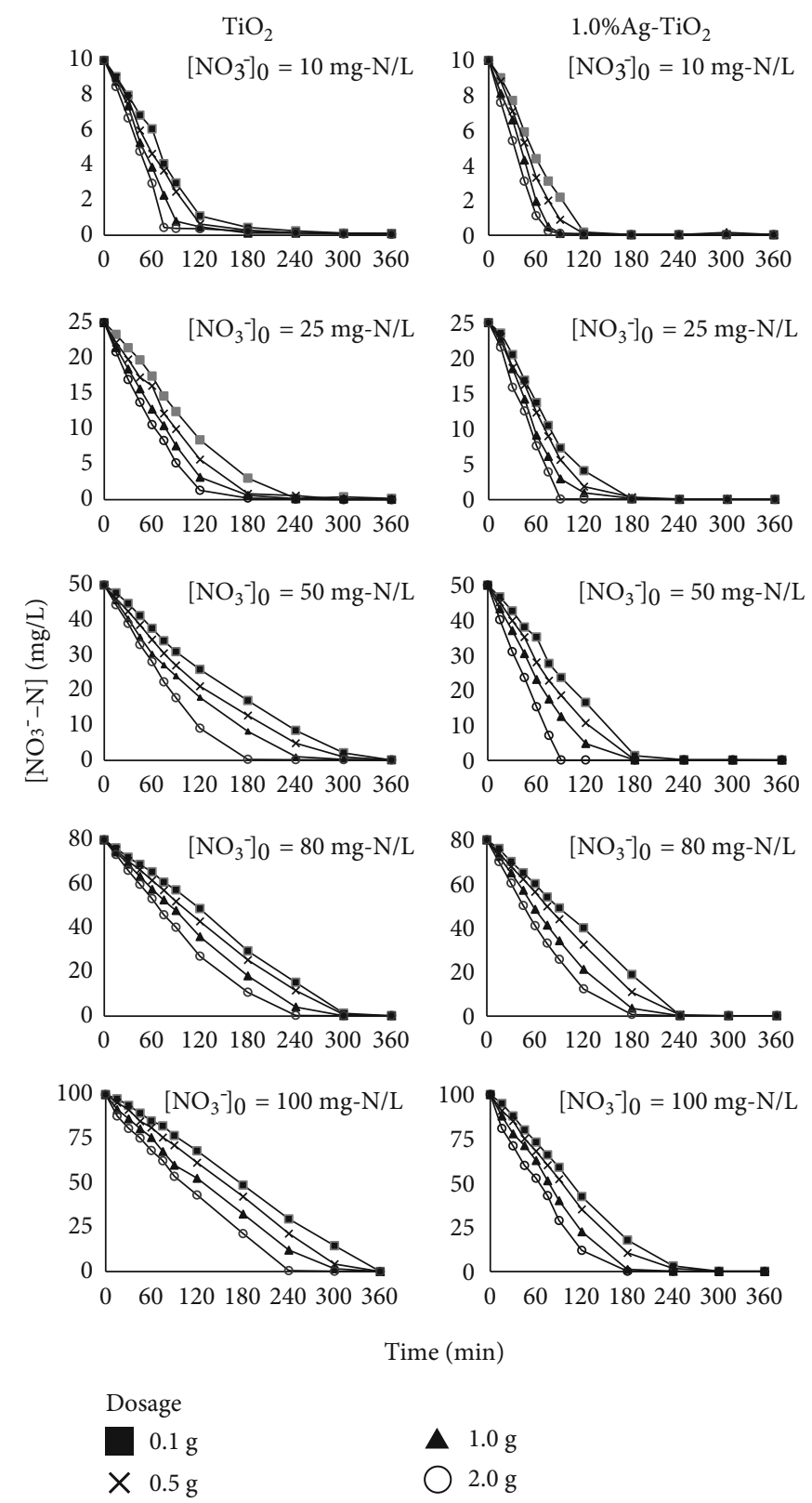

FIgURE 4: The concentrations of $\mathrm{NO}_{3}^{-}$of the photocatalytic reduction scheme under various $\left[\mathrm{NO}_{3}^{-}\right]_{0}$ and $\mathrm{TiO}_{2}$ and $1.0 \% \mathrm{Ag}$-TiO 2 dosages.

photocatalyst dosage in the photocatalytic reduction scheme. Based on the experimental results, $0.1 \mathrm{~g}$ of $\mathrm{Ag}$ $\mathrm{TiO}_{2}$ photocatalyst is advisable due to efficient removal of $\mathrm{NO}_{3}^{-}$(Figure 3).

To facilitate estimation of the remaining $\left[\mathrm{NH}_{4}^{+}\right]$in treated wastewater using photocatalytic reduction, the multiregression prediction equations of the theoretical remaining ammonium ion $\left(\left[\mathrm{NH}_{4}^{+}\right]_{T}\right)$, as a function of $\left[\mathrm{NO}_{3}^{-}\right]_{0}$ and photocatalyst dosage, are expressed in equations (14) and (15), respectively.

The prediction equation for $\mathrm{TiO}_{2}$ photocatalyst is

$$
\left[\mathrm{NH}_{4}^{+}\right]_{T}=-1.489+0.185\left[\mathrm{NO}_{3}^{-}\right]_{0}+2.698 \text { dosage }
$$

The prediction equation for $1.0 \% \mathrm{Ag}-\mathrm{TiO}_{2}$ photocatalyst is

$$
\left[\mathrm{NH}_{4}^{+}\right]_{T}=-3.744+0.274\left[\mathrm{NO}_{3}^{-}\right]_{0}+6.064 \text { dosage. }
$$

The relationships between $\left[\mathrm{NH}_{4}^{+}\right]_{T},\left[\mathrm{NO}_{3}^{-}\right]$, and photocatalyst dosage, as shown in equations (7) and (8), could be further applied to estimate the remaining $\left[\mathrm{NH}_{4}^{+}\right]$under various $\left[\mathrm{NO}_{3}^{-}\right]_{0}$ and photocatalyst dosages.

\section{Conclusion}

This research investigated the $\mathrm{NO}_{3}^{-}$removal efficiency of photocatalytic reduction process under various $\left[\mathrm{NO}_{3}^{-}\right]_{0}(10$, 


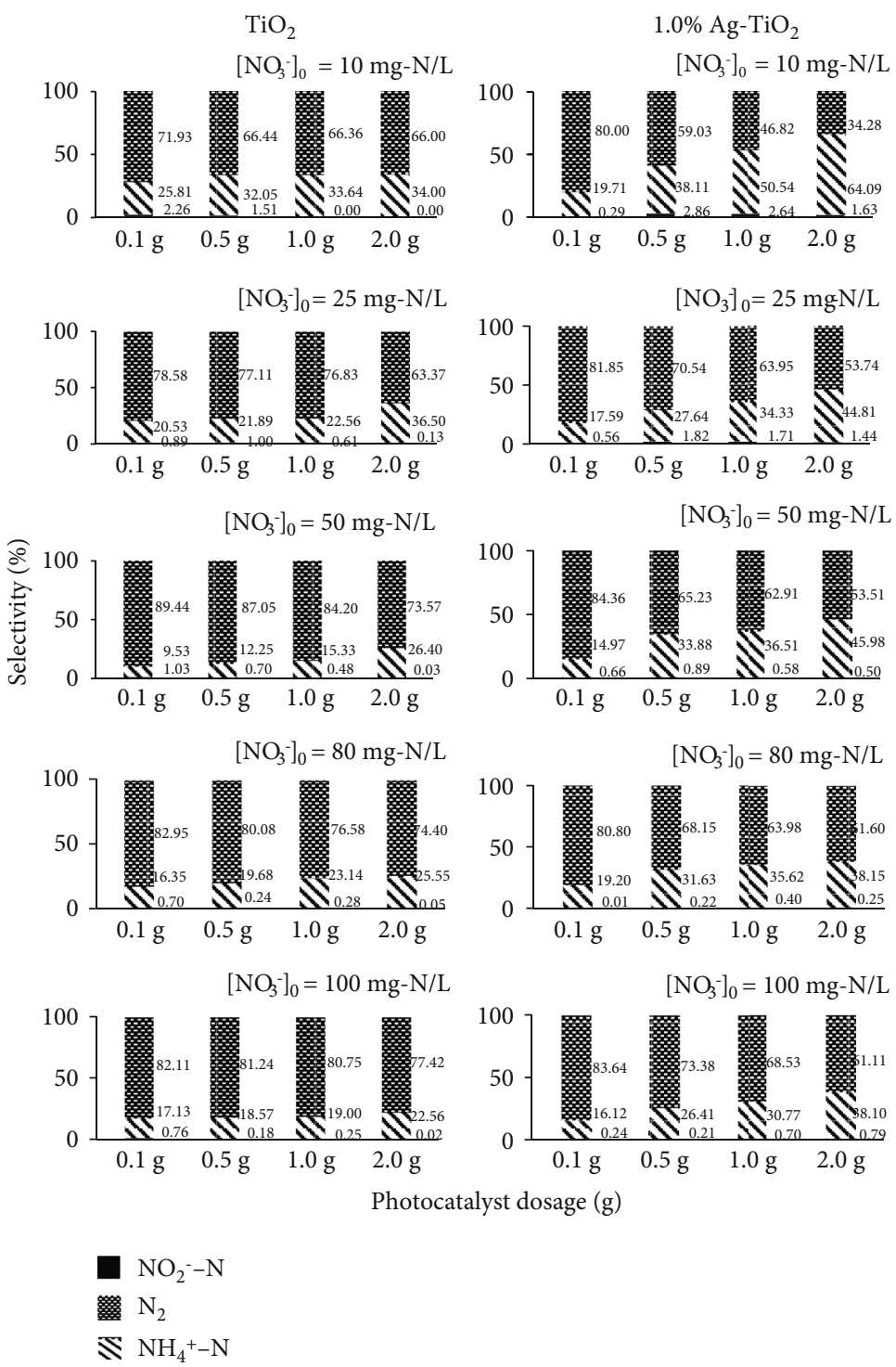

Figure 5: The catalytic selectivity of the photocatalytic reduction scheme under various $\left[\mathrm{NO}_{3}^{-}\right]_{0}$ and $\mathrm{TiO}_{2}$ and $1.0 \% \mathrm{Ag}-\mathrm{TiO}_{2}$ dosages.

TABLE 3: Results of multiple linear regression analysis.

\begin{tabular}{lccccc}
\hline Photocatalyst & $\begin{array}{c}\text { Independent } \\
\text { variables }\end{array}$ & $b$ & $\beta$ & $\begin{array}{c}t \\
\text { value }\end{array}$ & $\begin{array}{c}p \\
\text { value }\end{array}$ \\
\hline \multirow{2}{*}{$\mathrm{TiO}_{2}$} & {$\left[\mathrm{NO}_{3}^{-}\right]_{0}$} & 6.879 & 0.925 & 15.395 & 0.000 \\
& Dosage & 0.184 & 0.288 & 4.787 & 0.000 \\
& Constant & -1.489 & & -1.643 & 0.119
\end{tabular}

$R=0.969, R^{2}=0.939, F=129.955$, and $p$ value $<0.001$.

$\begin{array}{lccccc}1.0 \% A g- & {\left[\mathrm{NO}_{3}^{-}\right]_{0}} & 0.274 & 0.838 & 11.96 & 0.000 \\ \mathrm{TiO}_{2} & \text { Dosage } & 6.064 & 0.407 & 5.63 & 0.000 \\ & \text { Constant } & -3.744 & & -2.16 & 0.045\end{array}$

$R=0.955, R^{2}=0.911, F=87.30$, and $p$ value $<0.001$.

$25,50,80$, and $100 \mathrm{mg}-\mathrm{N} / \mathrm{L})$ and photocatalyst dosages $(0.1$, $0.5,1.0$, and $2.0 \mathrm{~g}$ ) using nanoparticle $\mathrm{TiO}_{2}$ and $1.0 \% \mathrm{Ag}-$ $\mathrm{TiO}_{2}$ photocatalysts under UVA. The $\mathrm{NO}_{3}^{-}$removal efficiency of both photocatalysts under experimental $\left[\mathrm{NO}_{3}^{-}\right]_{0}$ and photocatalyst dosages was between 98.96 and $99.98 \%$.
The catalytic selectivity products were $\mathrm{NH}_{4}^{+}, \mathrm{NO}_{2}^{-}$, and $\mathrm{N}_{2}$, with $\mathrm{N}_{2}$ accounting for a significant proportion of the selectivity. The doping of $\mathrm{TiO}_{2}$ with $\mathrm{Ag}^{+}$improved the removal efficiency of $\mathrm{NO}_{3}^{-}$. It was found that $\left[\mathrm{NO}_{3}^{-}\right]_{0}$ played a more important role in the remaining $\mathrm{NH}_{4}^{+}$than the photocatalyst dosage. Specifically, higher $\left[\mathrm{NO}_{3}^{-}\right]_{0}$ led to higher $\left[\mathrm{NH}_{4}^{+}\right]$in the treated wastewater. Multiple linear regression analysis confirmed the dominant role of $\left[\mathrm{NO}_{3}^{-}\right]_{0}$ in the remaining $\mathrm{NH}_{4}^{+}$.

\section{Data Availability}

The analysis data used to support the findings of this study are included within the supplementary information file(s).

\section{Conflicts of Interest}

The author(s) declare(s) that they have no conflicts of interest. 


\section{Acknowledgments}

The authors would like to express sincere gratitude to the Faculty of Engineering, Kasetsart University, Thailand, for the technical support.

\section{References}

[1] N. Tong, Y. Wang, Y. Liu et al., "PdSn/NiO/NaTaO3:La for photocatalytic ammonia synthesis by reduction of NO3- with formic acid in aqueous solution," Journal of Catalysis, vol. 361, pp. 303-312, 2018.

[2] Y. A. Shaban, A. A. El Maradny, and R. K. Al Farawati, "Photocatalytic reduction of nitrate in seawater using $\mathrm{C} / \mathrm{TiO}_{2}$ nanoparticles," Journal of Photochemistry and Photobiology A: Chemistry, vol. 328, pp. 114-121, 2016.

[3] D. Sun, W. Yang, L. Zhou, W. Sun, Q. Li, and J. K. Shang, "The selective deposition of silver nanoparticles onto $\left\{\begin{array}{lll}1 & 0 & 1\end{array}\right\}$ facets of TiO 2 nanocrystals with co-exposed $\left\{\begin{array}{lll}0 & 0 & 1\end{array}\right\} /\left\{\begin{array}{lll}1 & 0 & 1\end{array}\right\}$ facets, and their enhanced photocatalytic reduction of aqueous nitrate under simulated solar illumination," Applied Catalysis B: Environmental, vol. 182, pp. 85-93, 2016.

[4] K. Doudrick, T. Yang, K. Hristovski, and P. Westerhoff, "Photocatalytic nitrate reduction in water: managing the hole scavenger and reaction by-product selectivity," Applied Catalysis B: Environmental, vol. 136-137, pp. 40-47, 2013.

[5] R. Lucchetti, L. Onotri, L. Clarizia et al., "Removal of nitrate and simultaneous hydrogen generation through photocatalytic reforming of glycerol over "in situ" prepared zero-valent nano copper/P25," Applied Catalysis B: Environmental, vol. 202, pp. 539-549, 2017.

[6] E. Bahadori, A. Tripodi, G. Ramis, and I. Rossetti, "Semi-batch photocatalytic reduction of nitrates: role of process conditions and co-catalysts," ChemCatChem, vol. 11, no. 18, pp. 46424652, 2019.

[7] Z. W. Lipsky and G. K. German, "Ultraviolet light degrades the mechanical and structural properties of human stratum corneum," Journal of the Mechanical Behavior of Biomedical Materials, vol. 100, article 103391, 2019.

[8] T. F. Anderson, “Artificial light sources," Dermatologic Clinics, vol. 4, no. 2, pp. 203-215, 1986.

[9] T. Rojviroon and S. Sirivithayapakorn, "E. coliBacteriostatic action using TiO2Photocatalytic reactions," International Journal of Photoenergy, vol. 2018, 12 pages, 2018.

[10] T. Rojviroon, O. Rojviroon, and S. Sirivithayapakorn, "Photocatalytic decolourisation of dyes using TiO2thin film photocatalysts," Surface Engineering, vol. 32, no. 8, pp. 562-569, 2016.

[11] M. Long, J. Wang, H. Zhuang, Y. Zhang, H. Wu, and J. Zhang, "Performance and mechanism of standard nano-TiO 2 (P-25) in photocatalytic disinfection of foodborne microorganisms Salmonella typhimurium and Listeria monocytogenes," Food Control, vol. 39, pp. 68-74, 2014.

[12] J. Yuan, E. Wang, Y. Chen, W. Yang, J. Yao, and Y. Cao, "Doping mode, band structure and photocatalytic mechanism of B$\mathrm{N}$-codoped $\mathrm{TiO}_{2}$," Applied Surface Science, vol. 257, no. 16, pp. 7335-7342, 2011.

[13] K. Nakata and A. Fujishima, " $\mathrm{TiO}_{2}$ photocatalysis: design and applications," Journal of Photochemistry and Photobiology C: Photochemistry Reviews, vol. 13, no. 3, pp. 169-189, 2012.

[14] F. Zhang, R. Jin, J. Chen et al., "High photocatalytic activity and selectivity for nitrogen in nitrate reduction on ${ }_{\mathrm{Ag} / \mathrm{TiO}}$ cata- lyst with fine silver clusters," Journal of Catalysis, vol. 232, no. 2, pp. 424-431, 2005.

[15] H. O. N. Tugaoen, S. Garcia-Segura, K. Hristovski, and P. Westerhoff, "Challenges in photocatalytic reduction of nitrate as a water treatment technology," Science of The Total Environment, vol. 599-600, pp. 1524-1551, 2017.

[16] EPA, Final aquatic life ambient water quality criteria for ammonia-freshwater, 2013, https://www.federalregister.gov/ documents/2013/08/22/2013-20307/final-aquatic-lifeambient-water-quality-criteria-for-ammonia-freshwater2013.

[17] L. Li, Z. Xu, F. Liu et al., "Photocatalytic nitrate reduction over $\mathrm{Pt}-\mathrm{Cu} / \mathrm{TiO}_{2}$ catalysts with benzene as hole scavenger," Journal of Photochemistry and Photobiology A: Chemistry, vol. 212, no. 2-3, pp. 113-121, 2010.

[18] J. Sá, C. A. Agüera, S. Gross, and J. A. Anderson, "Photocatalytic nitrate reduction over metal modified $\mathrm{TiO}_{2}$," Applied Catalysis B: Environmental, vol. 85, no. 3-4, pp. 192-200, 2009.

[19] T. Yang, K. Doudrick, and P. Westerhoff, "Photocatalytic reduction of nitrate using titanium dioxide for regeneration of ion exchange brine," Water Research, vol. 47, no. 3, pp. 1299-1307, 2013.

[20] K. Kobwittaya and S. Sirivithayapakorn, "Photocatalytic reduction of nitrate over $\mathrm{TiO}_{2}$ and $\mathrm{Ag}$-modified $\mathrm{TiO}_{2}$," Journal of Saudi Chemical Society, vol. 18, no. 4, pp. 291-298, 2014.

[21] J. M. A. Freire, M. A. F. Matos, D. S. Abreu et al., "Nitrate photocatalytic reduction on $\mathrm{TiO}_{2}$ : metal loaded, synthesis and anions effect," Journal of Environmental Chemical Engineering, vol. 8, no. 4, article 103844, 2020.

[22] S. Cao, R. Du, Y. Peng, B. Li, and S. Wang, "Novel two stage partial denitrification (PD)-Anammox process for tertiary nitrogen removal from low carbon/nitrogen $(\mathrm{C} / \mathrm{N})$ municipal sewage," Chemical Engineering Journal, vol. 362, pp. 107$115,2019$.

[23] L. M. Santos, W. A. Machado, M. D. França et al., "Structural characterization of Ag-doped $\mathrm{TiO}_{2}$ with enhanced photocatalytic activity," RSC Advances, vol. 5, no. 125, pp. $103752-$ 103759, 2015.

[24] S. Krejčíková, L. Matějová, K. Kočí et al., "Preparation and characterization of Ag-doped crystalline titania for photocatalysis applications," Applied Catalysis B: Environmental, vol. 111-112, pp. 119-125, 2012.

[25] K. Gupta, R. P. Singh, A. Pandey, and A. Pandey, "Photocatalytic antibacterial performance of $\mathrm{TiO}_{2}$ and Ag-doped $\mathrm{TiO}_{2}$ against S. aureus. P. aeruginosa and E. coli," Beilstein Journal of Nanotechnology, vol. 4, pp. 345-351, 2013.

[26] N. Krasae and K. Wantala, "Enhanced nitrogen selectivity for nitrate reduction on $\mathrm{Cu}-\mathrm{nZVI}$ by $\mathrm{TiO}_{2}$ photocatalysts under UV irradiation," Applied Surface Science, vol. 380, pp. 309$317,2016$.

[27] M. Ahamed, M. A. M. Khan, M. J. Akhtar, H. A. Alhadlaq, and A. Alshamsan, "Ag-doping regulates the cytotoxicity of $\mathrm{TiO}_{2}$ nanoparticles via oxidative stress in human cancer cells," Scientific Reports, vol. 7, no. 1, p. 17662, 2017.

[28] Y. Luo, S. Yu, B. Li et al., "Synthesis of (Ag,F)-modified anatase TiO2nanosheets and their enhanced photocatalytic activity," New Journal of Chemistry, vol. 40, no. 3, pp. 2135-2144, 2016.

[29] R. Saravanan, D. Manoj, J. Qin et al., "Mechanothermal synthesis of $\mathrm{Ag} / \mathrm{TiO}_{2}$ for photocatalytic methyl orange degradation and hydrogen production," Process Safety and Environmental Protection, vol. 120, pp. 339-347, 2018. 
[30] N. T. Minh and B.-K. Lee, "Feasibility of silver doped $\mathrm{TiO}_{2} /-$ glass fiber photocatalyst under visible irradiation as an indoor air germicide," International Journal of Environmental Research and Public Health, vol. 11, pp. 3271-3288, 2014.

[31] L. Lu, G. Wang, Z. Xiong et al., "Enhanced photocatalytic activity under visible light by the synergistic effects of plasmonics and $\mathrm{Ti}^{3+}$-doping at the Ag/TiO2- heterojunction," Ceramics International, vol. 46, no. 8, pp. 10667-10677, 2020.

[32] A. Herissan, J. Meichtry, H. Remita, C. Colbeau-Justin, and M. Litter, "Reduction of nitrate by heterogeneous photocatalysis over pure andradiolytically modified $\mathrm{TiO}_{2}$ samples in the presence of formic acid," Catalysis Today, vol. 281, 2016.

[33] L. Elsellami, F. Dappozze, A. Houas, and C. Guillard, "Effect of $\mathrm{Ag}^{+}$reduction on the photocatalytic activity of Ag-doped $\mathrm{TiO}_{2}$," Superlattices and Microstructures, vol. 109, pp. 511518, 2017.

[34] X. F. Lei, X. X. Xue, and H. Yang, "Preparation and characterization of Ag-doped $\mathrm{TiO}_{2}$ nanomaterials and their photocatalytic reduction of $\mathrm{Cr}(\mathrm{VI})$ under visible light," Applied Surface Science, vol. 321, pp. 396-403, 2014.

[35] D. Zhang, B. Wang, X. Gong, Z. Yang, and Y. Liu, "Selective reduction of nitrate to nitrogen gas by novel $\mathrm{Cu}_{2} \mathrm{O}-\mathrm{Cu}_{0} @ \mathrm{Fe}_{0}$ composite combined with $\mathrm{HCOOH}$ under UV radiation," Chemical Engineering Journal, vol. 359, pp. 1195-1204, 2019.

[36] W. Gao, R. Jin, J. Chen et al., "Titania-supported bimetallic catalysts for photocatalytic reduction of nitrate," Catalysis Today, vol. 90, no. 3-4, pp. 331-336, 2004.

[37] F. Zhang, Y. Pi, J. Cui, Y. Yang, X. Zhang, and N. Guan, "Unexpected selective photocatalytic reduction of nitrite to nitrogen on silver-doped titanium dioxide," The Journal of Physical Chemistry C, vol. 111, no. 9, pp. 3756-3761, 2007.

[38] S. Parastar, S. Nasseri, S. H. Borji et al., "Application of Agdoped TiO2nanoparticle prepared by photodeposition method for nitrate photocatalytic removal from aqueous solutions," Desalination and Water Treatment, vol. 51, no. 37-39, pp. 7137-7144, 2013.

[39] J. Huang, L. Ding, Y. Xi et al., "Efficient silver modification of $\mathrm{TiO}_{2}$ nanotubes with enhanced photocatalytic activity," Solid State Sciences, vol. 80, pp. 116-122, 2018.

[40] R. Qian, H. Zong, J. Schneider et al., "Charge carrier trapping, recombination and transfer during $\mathrm{TiO}_{2}$ photocatalysis: an overview," Catalysis Today, vol. 335, 2018.

[41] S. Buda, S. Shafie, S. A. Rashid, H. Jaafar, and N. F. M. Sharif, "Enhanced visible light absorption and reduced charge recombination in AgNP plasmonic photoelectrochemical cell," Results in Physics, vol. 7, pp. 2311-2316, 2017.

[42] B. Xin, L. Jing, Z. Ren, B. Wang, and H. Fu, "Effects of simultaneously doped and deposited Ag on the photocatalytic activity and surface states of $\mathrm{TiO}_{2}$," The Journal of Physical Chemistry B, vol. 109, no. 7, pp. 2805-2809, 2005.

[43] G. Tokazhanov, E. Ramazanova, S. Hamid, S. Bae, and W. Lee, "Advances in the catalytic reduction of nitrate by metallic catalysts for high efficiency and $\mathrm{N}_{2}$ selectivity: a review," Chemical Engineering Journal, vol. 384, p. 123252, 2020. 